\title{
Tacit Knowledge Sharing and Project Performance. Does the Knowledge Workers' Personal Branding Matter?
}

\author{
Wioleta Kucharska \\ Department of Marketing, Faculty of Management and Economics, Gdansk University of Technology, Gdansk, Poland
}

Copyright $(2017$ by authors, all rights reserved. Authors agree that this article remains permanently open access under the terms of the Creative Commons Attribution License 4.0 International License

\begin{abstract}
Tacit knowledge sharing is the real challenge for knowledge management today. Network economy has completely changed the role of knowledge workers who now become independent tacit knowledge producers. Bearing this fact in mind, the author studied how tacit knowledge sharing affects the process of building a personal brand and project performance. For this purpose, the authors conducted a study among Polish professionals with different roles and experience in managing projects in various industries. The data collected during the study has been analysed using the equal structural modelling method. The results indicate that tacit knowledge sharing is used when developing a personal brand of knowledge workers who take care about the personal reputation. The intermediary role of personal branding in the relationship of tacit knowledge sharing and project performance points to a new context of tacit knowledge sharing as a key factor of knowledge management in learning organisations, which can be used for designing incentive schemes. Tacit Knowledge Sharing is also presented as a very sensitive and specific variable interesting for further research.
\end{abstract}

Keywords Tacit Knowledge, Personal Branding, Project Performance, Project Management, Knowledge Management, Network Economy

\section{Introduction}

Innovation, relationships, cooperation, and knowledge are key factors which determine a competitive advantage in the network economy [1-3]. A network serves as a contemporary form of market process coordination. Network economy (NE), according to the Toffler's [4] idea of prosumerism, is founded on collaboration of individual creators based on a network of values instead of hierarchical dependencies. Another feature of $\mathrm{NE}$ is that it imposes symmetry of advantages [5]. In such conditions, a set of relationships of a company in an arrangement: "one to many" changes into a relationship "many to many" (networking) and creates a complete network of company values including: business partners and customers (external network), as well as the company's employees (internal network). Knowledge, as a source of innovation, determines an advantage of one network arrangement over another. This situation has completely changed the role of knowledge workers who now become independent knowledge producers. Being a source of intellectual capital they can, independently from for example a corporate hierarchy, distribute the value which they generate in an already existing network, or they can build such a network themselves. The named network, in pursuit of its highest efficiency, looks for such knowledge workers in order to increase its productivity. Intellectual capital as a source of value in the network economy is generated outside hierarchies. Thus, the network economy imposes building a relational equity [6] which is the essence of efficiency in a network. In reference to Hunt's [7] resource-advantage (R-A) theory the relationship in itself also constitutes a resource. Thus personal branding of knowledge workers, whose goal is to build business relationships, becomes a natural consequence of their empowerment in the contemporary economy. The importance of knowledge and relationship in the process of network value creation by innovation is significant. In light of all the above, identifying valuable innovations takes place as a result of symmetrical co-creation and cooperation of members of a consciously configured value network. Innovation consists in implementing a new or significantly improved product (a good or a service) or process, a new marketing method or a new organisational method, into business practice, organisation of a work place or relationships with the surrounding world [8]. An organisation may create innovations both within an internal and external network as places where ideas are born. Likewise, the innovations may be dedicated to internal and 
external values of the network as a beneficiary of the bundle of benefits such innovation may bring. Innovation equals change. Efficient implementation of changes more and more frequently is done through a project. Worthy of particular attention here are project organisations called temporarily for the purpose of a specific goal (business product). Teams of such organisations usually include people with different skills and knowledge who come from different functional divisions of an organisation, and sometimes even from different organisations. Project management is linked to the idea of organisation as a network of activities by Czarniawska [9], under this principle it can be assumed that functional and process management, however necessary, is not sufficient in the network economy. Project organisations are the answer to the necessity of working in a change implementation mode. Efficiently functioning companies organise a project, whose goals is to develop and implement a change, in such a way as to achieve desired results in time and framework of allotted resources what was pointed by Portny [10]. Apart from the best known methodologies and approaches to project management popularized by Project Management Institute (PMI) and Organisation of Government Commerce (OGC), such as PRINCE2, Project Management Body of Knowledge (PMBoK), OPMA Competence Baseline, ,agile” methodologies, Project Cycle Management (PCM) there are many approaches now deployed by companies successfully in innovation implementation. The probability of an effective change (innovation) implementation in an organisation thanks to the application of a project approach is even greater, since each of the above mentioned methodologies of project management enjoins the people responsible for its implementation to maintain a continuum of business justification of an enterprise (PRINCE2). Keeping the information organised and complete, and free flow of knowledge assured by the project method of change implementation are an effective way to achieve a final success not only related to a particular innovation, but also a long term success achieved thanks to creating a knowledge sharing culture in a learning organization.

\subsection{Knowledge Workers as Tacit Knowledge Producers}

According to McInterney [11] knowledge management, in other words the process of creating new knowledge, involves identifying sources of knowledge, its elicitation, and distribution. Combining the existing knowledge in new ways and the contextuality of knowledge determine the meaning of tacit knowledge. The way tacit knowledge is viewed these days places strong emphasis on its significance within organisations. As opposed to explicit, tacit knowledge is absolutely novel and in the result very beneficial for companies. Tacit knowledge is specific: it is produced and stored in human's minds and being an intangible asset it is closely related to social capital. Knowledge workers are the main source of know-how and experience, the knowledge is their major work tool and resource $[12,13]$.

Modern network organisations which desire to be innovative and want to create market advantage must find a way to harness this resource, which as a matter of fact is not in their possession, and transform tacit into explicit [14-17]. Explicit knowledge is easy to transfer because it can be codified. Tacit knowledge is hard to codify or record, hence it is acquired through a practical experience in a relevant context [18]. Because tacit knowledge to a great extent relies on its context it cannot be codified. Any modifications to the context nullify this codified knowledge, provided the codification is even possible with the dynamics of the present day work environment.

The network economy, as a way to function in a contemporary economy, often requires the ability to work in temporary project teams. Relationships between people as a resource enhancing transfer of knowledge have an advantage over system resources because of the effectiveness of this process. Even best configurated Transactive Memory Systems (TMS) are unwieldy in relation to a direct contextual transfer. Delivering value through knowledge is making sure that the knowledge needed for effective action is delivered [19]. Delivering value through knowledge does not only require an efficient TMS but also a diligent management of the collaboration culture of a temporary organisation in order to ensure free flow of Tacit Knowledge Sharing.

Referring to the network economy, another feature of a network as a today's business infrastructure is that it imposes symmetry of advantages. In such conditions, a set of relationships of a company in an arrangement: "one to many" changes into a relationship "many to many" (networking) and creates a complete network of company values including: business partners and customers (external network) as well as the company's employees (internal network). Knowledge, as a source of innovation, determines the advantage of one network arrangement over another. This situation has completely changed the role of knowledge workers who now become independent knowledge producers. Being a source of intellectual capital they can, independently from for example a corporate hierarchy, distribute the value which they generate in an already existing network, or they can build such a network themselves. In pursuit of its highest efficiency, the said network looks for such knowledge workers so as to increase its productivity. Intellectual capital as a source of value in the network economy is generated outside hierarchies, thus the network economy imposes building a relational equity which is the essence of efficiency in a network. According to mentioned Hunt's [7] resource-advantage (R-A) theory the relationship in itself also constitutes a resource.

On the other hand, Wit and Meyer [20] noticed the problem of asymmetric distribution of benefits between networked brokers (network leader) and actors (other networked companies) as one of a networked company's strategy paradoxes. Referring to all the above the author 
claims that the same paradox is observed in the relationship between companies (knowledge brokers) and their knowledge workers (actors). Employees in networked knowledge organisations are more often confronted with new experiences which help them develop their skills and broaden their minds.

Companies are interested in capturing the new tacit knowledge which is produced in minds of their workers every day. They build Transactive Memory Systems (TMS), Collaborative Social Networks and the like, whose goal is to gather, store and distribute knowledge within an organisation. The problem of a contemporary organisation however is not how to store or distribute the knowledge within established rights but how to capture and gather the new knowledge which is a source of innovation. The process which will allow to transform tacit into explicit is then the key for an organisation's development.

Sharing informal knowledge is an informal voluntary act of the knowledge owner and it is a dynamic social process characterised by profound human interactions. Besides, the act of commitment cannot be formalised, for you cannot express your commitment non-commitally. Indeed, the structure of perception throws light on all the rest [21]. Moreover, it is not in the best interest of workers to give away their tacit knowledge, since this knowledge provides them with a personal advantage in the network system in which they function.

The paradoxical situation of knowledge workers is that they can best develop through interaction with other like-minded people, which should encourage tacit knowledge sharing, at the same time however tacit knowledge sharing rids them of their advantage in a given network system. On the other hand, effective tacit knowledge sharing builds their position, so it is a situation in which loss leads to profit. At the same time, excessive pursuit of profit through, e.g. unequal distribution of benefits may lead to loss being a consequence of lost relationships, which are the valuable network connection.

Making a reference to the paradigm of information and knowledge asymmetry in the network economy [22], although the position of the knowledge broker will be stronger than the position of the actor [23], because of more increasingly unrestrained circulation of explicit knowledge in the economy, and the growing significance of tacit knowledge as the source of competitive advantage, the role of tacit knowledge producers such as knowledge workers will continue to increase.

Thus, the position of knowledge workers in the network economy driven by knowledge is absolutely subjective. Their interdependence is a fact. They can freely switch on or switch off to/from a network of values of their own choice, according to expected financial or other gain. For companies it is connected with the need to adapt their ways of functioning to new conditions. Will the consequence of changes connected with the subjective role of relationships and knowledge, with special emphasis on tacit knowledge as a source of innovation and knowledge workers as tacit knowledge owners; is a socially driven evolution or revolution in the network economy? Opinions are divided, but one is a fact: as Solis [24] observed, "This is the end of business as usual."

\subsection{New Trends}

According to the Eurostat data [8], the average rate of self-employment in the EU equals $13.5 \%$. It is the highest in Greece (30\% of the employed) and in Italy (22\%). The index above the EU average can also be noted for Poland, where the number of self-employed persons in 2015 was 2.94 million, which equals $17.7 \%$. It is by $6.4 \%$ more than in 2010 . The Deutsche Bank survey [25] on the other hand reports that the percentage of self-employment is significantly higher for liberal professions $-72.4 \%$ of such persons run their own one-man businesses. Buckley and Strange [26] pointed out that freelancing over the last two decades is an effect of transformation from a predominantly precariat shadow workforce serving as substitutes for employees to a far more diverse workforce incorporating high earning and highly skilled workers who serve a dynamic role for businesses; mainly working as complements to employees and frequently undertaking innovation.

This transformation, as they claim, has been paralleled with a rapid rise in the number of freelancers in the workforce and the increasing use of flexible working and outsourcing business models by firms. This trend is also attractive for knowledge workers. What they especially appreciate is flexibility in terms of when and where they work. This is what affects their efficiency and development. Freelancers' weak spot is their sense of freedom as opposed to the modern-day slavery [27], self-determination, the sense of self-control and living according to ones' own values and aspirations, responsibility for oneself and others. Corporations will not give them this. An ethical work climate leads to more trust in the company, stronger attachment from employees, lower absenteeism and turnover rate, higher productivity, a more positive attitude toward work and good conduct from employees [28]. Several studies find a positive relationship between a company's ethical climate and employee job satisfaction [28, 29].

The Corporate Social Responsibility (CSR) framework and good reputation may indirectly contribute to job satisfaction and lower employee turnover by invoking positive reactions from external groups, such as family and friends [30]. The empirical findings made by Lee et al. [31] suggest that perceived cultural fit and CSR capability significantly affect company's perception and, consequently, employee attachment and performance. Singhapakdi, et al. [32] empirical research results also confirm that a CSR strategy has a positive impact on employees' quality of work life. Therefore, this study's recommendation is that a CSR should be widely adopted by organizations. 
The consequence of this approach is growing popularity of employee branding. The research by Dabirian et al. [33] identifies seven employer branding value propositions that current, former, and potential employees care about when they collectively evaluate employers. These propositions for „best places to work” include (1) social elements of work $33 \%$, (2) interesting and challenging work tasks $23 \%$, (3) economic issues tied to compensation $(16 \%),(4)$ the extent to which skills can be applied in meaningful ways $14 \%$, (5) work/life balance $9 \%$.

Thus, the social factor next to the opportunity to develop as a result of challenging work is crucial for employees today. Taking into consideration all the above, to sum up, we can say that the consequence of changing the way of functioning of the whole business environment in the network economy is a socially driven evolution of businesses based on knowledge and knowledge workers.

The term 'Enterprise 2.0' has been used to describe how concepts and technologies from Web 2.0 have been deployed into companies. One of the paradigms chosen for improving the innovation processes within the Enterprise 2.0 context is Open Innovation, based on the collaborative creation and development of ideas and products.

The key feature of this new paradigm is that the knowledge is exploited in a collaborative way, flowing not only among internal but also external sources [34]. Collaborative culture in the era of the network economy is not only a set of values and norms which give an identity to each enterprise but also a valuable element of intellectual capital and source of innovation and business advantage [35]. The conversion of both Intellectual Capital and Social Capital is facilitated by knowledge sharing [36], which in the era of network economy often takes place with the use of social media [37,38] and results in the creation of Collaborative Networks, also called Communities of Practice.

Facilitating the free flow of knowledge across the organisational boundary between knowledge workers can help integrate explicit knowledge bases of companies more effectively and lead to the creation of new tacit knowledge. Social Knowledge Management is crucial to this process. Knowledge Management tools and best practices can have added benefit in the field of knowledge production, consumption, and redistribution. As the majority of organisational knowledge is tacit and cannot be easily codified, effective processes need to be implemented to enable tacit knowledge transfer into explicit across the boundary between groups and individuals.

\subsection{Knowledge Workers and Personal Branding}

The notion of personal branding pointed out by Peters [39] has taken on major importance in the blooming era of social media what was mentioned by Dutta [40] and Karaduman[41] and refers to all users of the medium what was highlighted by Shepherd [42]. Labrecque, Markos and Milne [43] also imply that people today use social media actively in order to create their personal brands. According to the idea of co-branding $[44,45]$ drawing from the theory of planned behaviour [46], and referring to Shepherd's [42] and Khedher's [47] definitions of personal branding as a planned process in which people make efforts to market themselves an assumption has been made which says that a personal brand reputation and recommendation is crucial in the network economy for the personal success. The success understood as a personal goals achievement. All goals connected not only with the professional and business life but also with the social life connected with being a part of communities. With regard to the mentioned idea of "prosumerism" [4], one can hypothesize that there is a certain degree of probability that personal brands in the network economy, e.g. in professional networks, collaborative networks or even in the social media, predominantly constitute an opportunity for self-presentation [68]. A self-expression is a form of affirmation of one's self [48-50]. Consumer engagement with self-expressive brands: brand love and WOM outcomes always take place in a social context meaning $[48,50-52]$ so-called "reference groups" have an influence on both the self-image and the act and ways of an individual's self-expression. Referring to Erikson [53], who described identity in a less volatile era as "an individual's link with the unique values", we can say that the expression of a personal identity, and particularly personal values, has a strong influence on personal brand recognition. A personal brand, analogically to a commercial brand, is about gathering the capital in minds of friends and colleagues. Creating a reputation of one's own personal brand in the era of the network economy, including social media, is crucial. Consciously creating a desired personal image, based on credible and coherent information, in order to generate income and personal development by pursuing ambitious professional challenges is very popular among professionals [54].Knowledge workers become increasingly more autonomous today. Thus, the idea of personal branding is in agreement with human nature, which is characterised by the inner need to belong and be recognised. The transience of peer to peer relation in the network economy makes knowledge workers to function as an independent personal brand whose reputation is significant in the process of network value creation. This can be a stronger motivator for knowledge sharing than the trust which is difficult to gain in a cursory reality of transient project organisation.

Contextuality of knowledge and the key role of knowledge workers in modern network arrangements contribute to the growing self-awareness of the need for personal development among such workers. It can be assumed that a vital element of the training is intellectual dexterity in various contexts. Skills of knowledge workers become sales objects, which make them vividly interested in completing, training and expanding their knowledge which requires an attitude open to knowledge but also to colleagues with whom they come in contact, and who enhance such knowledge 
creation. Knowledge creating is a dynamic social process characterised by profound human interactions. Sharing informal knowledge is an informal voluntary act of the knowledge owner. It is impossible to formalise the act of commitment, for you cannot express your commitment in a not-commitment way. That is why skills of producing, storing and sharing tacit knowledge depend also on personality, skills, explicit knowledge, and the ability to use external resources of explicit knowledge, as well as own and other people's experiences. Hence, this article's goal is to study the relationship between the construct of personal branding of knowledge workers who work using a project method and tacit knowledge sharing as determinants of innovation.

\subsection{Tacit Knowledge Sharing: Challenge for Knowledge Management}

Knowledge management is a process of creating new knowledge, identifying sources of knowledge, as well as elicitation and distribution of knowledge [11]. Tacit knowledge is crucial today because, in contrast to explicit knowledge, it is absolutely novel, which makes it truly advantageous. Tacit knowledge is specific: it is produced and stored in people's minds. Tacit knowledge as an intangible asset is closely related to social capital. The main source of know-how and experience are knowledge workers, for whom knowledge is the major tool and resource of their work. In order to become innovative and generate market advantage a modern network organisation must manage this resource, which in no way belongs to it, until tacit knowledge is transferred into explicit knowledge. Explicit knowledge can be codified and is easier to transfer compared to tacit which is hard to codify or write down and thus commonly needs to be acquired through practical experience in a relevant context. Since this type of knowledge is contextual, it basically cannot be codified because a changed situational context causes the codified knowledge to expire, if only, with the present day dynamics of the environment, an organisation will manage to codify it. What is the key then to tacit knowledge management when it comes to independent knowledge creators? How to transfer tacit knowledge? How to convert tacit to explicit knowledge? How to distribute tacit knowledge in order to develop an organisation, increase its innovation and build a market advantage? The Munns [55], Park and Lee [16], Buvik and Rolfsen [56] suggest that the key to meet this challenge is to build an organisational culture which encourages knowledge sharing and one where relationships are based on trust and cooperation. According to the authors of this paper the list of elements should include one more, and in our opinion the strongest, motivator which is one's own personal gain based not on financial benefits related to a current salary but on creating a perspective of future income whose foundation is a good reputation of one's personal brand.

Sharing knowledge by co-workers is essential for organizations. Open sharing of relevant knowledge has the potential to lower costs and optimize processes. The lack of sharing may harm organizations and even render their processes ineffective [57]. Polanyi [21] was among the first to classify knowledge as explicit or tacit. Over time, this classification was adopted by others. As opposed to explicit, tacit knowledge is absolutely novel and, for this reason, beneficial for organizations. This form of knowledge is specific; it is produced and stored in people's minds and being an intangible asset it is closely related to social capital. Intangible assets become increasingly likely to decide about a competitive advantage of companies. They are not easily noticeable and hard to measure; however, their indirect influence proves to play a crucial role in value creation. A lot of studies have been dedicated to the general idea of explicit knowledge sharing, but only a few focuses on tacit knowledge [57-59]. The aim of the presented study is to prove that tacit knowledge sharing is a tool that builds a personal brand of knowledge workers in a project environment which in result leads to the performance improvement.

\section{Materials and Methods}

The goal of this research is to highlight that personal branding of knowledge workers can be a natural motivator to share their tacit knowledge which also affects final project performance. In order to prove it, a research model has been designed, where a theoretical assumption was made related to the influence of knowledge management on Tacit Knowledge Sharing and project performance, with personal branding playing the role of a mediator. Figure 1 illustrates the assumed conceptual framework [67]. The relationship between general knowledge management and project performance was examined by Reich, Gemino and Sauer [60] and Calvo-Mora et al [61]. Based on their research, the following hypotheses have been formulated:

H1: Knowledge Management has a positive influence on Project Performance.

H2: Knowledge Management has a positive influence on Tacit Knowledge Sharing.

In relation to the above hypotheses, as well as the research related to the influence of Tacit Knowledge Sharing on explicit knowledge [14-16,58,59], following a logical inference, it has been assumed that analogically to knowledge sharing, tacit knowledge sharing has a positive influence on project performance, which is reflected in hypothesis 3 :

H3: Tacit Knowledge sharing has a direct positive influence on Project Performance

Based on the theory of planned behavior [47] and the idea of personal branding [39-43] a hypothesis has been developed which talks about tacit knowledge sharing in order to build a personal brand, namely: Tacit Knowledge sharing has a positive influence on Personal Branding of the team member who shares his knowledge. A significant 
determinant of sharing creates a positive attitude of other team members towards the sharing member of the team. Tacit knowledge sharing affects a positive attitude towards that member's personal brand.

H4: Tacit Knowledge sharing has a positive influence on Personal Branding of the team member who shares his own tacit knowledge.

Regarding Project Performance, and as a consequence of the above assumption that personal branding is a sharing motivator, a hypothesis has been made which says that personal branding is a mediator between tacit knowledge and project performance, hence the hypothesis below:

H5: Personal Branding of team members has a positive influence on Project Performance.

Figure 1 illustrates the assumed conceptual framework [67].

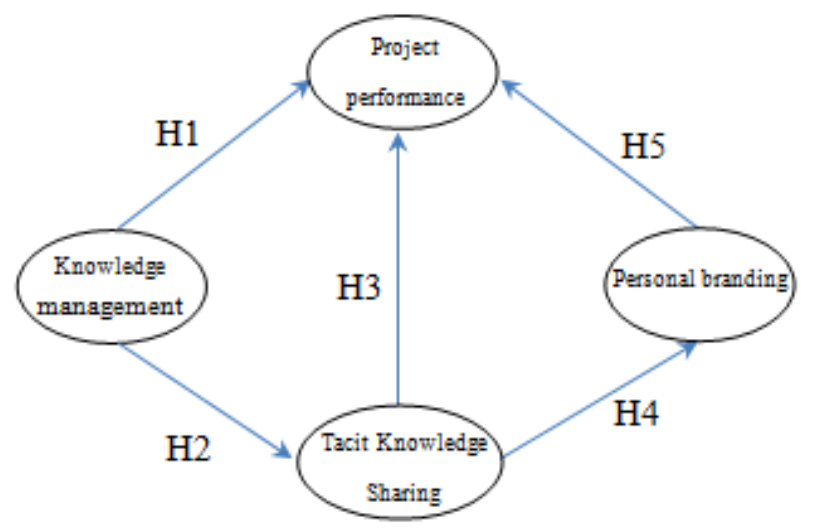

Figure 1. Conceptual framework

\subsection{Methodology}

The study was conducted based on the data originally collected among Polish professionals with different roles and experience in managing projects in various industries. The sample comprised $60 \%$ of team members, $19 \%$ of project managers, $15 \%$ of team leaders, $3 \%$ of steering committee, $2 \%$ of project sponsors and $1 \%$ others. The industries included in the study are as follows: $27 \%$ production, $16 \%$ marketing \& sales, $12 \%$ IT, $9 \%$ science \& education, $7 \%$ services, $6 \%$ construction, $5 \%$ society projects, $5 \%$ media, $4 \%$ logistics \& supply, $3 \%$ finance, $3 \%$ controlling, $3 \%$ others. $60 \%$ of the respondents were male and $40 \%$ were female. The data was collected from January to February 2016 with the use of a questionnaire. The questionnaire's design was based on measurement scales and their sources presented in Appendix 1. The respondents reacted to statements based on a 7-point Likert scale, which goes from 1 - definitely NOT, through 4 - neither YES nor NOT, until 7 - definitely YES. The questionnaire was preceded by a short introduction explaining the purpose and subject matter of the study. The first qualifying question directly referred to the subject matter of the study and regarded the respondent's affiliation to any project whose performance was assessed. The subsequent part of the structure of the questionnaire led from general to detailed questions which required more precise answers. The proper study was preceded by a pilot study ( 24 persons). The pilot study made it possible to optimize statements. In effect, for the benefit of the study reliability, problematic statements have been eliminated. Data collection took place electronically, using mainly the "snowball method", and started with managers who were then willing to recommend our study to their acquaintances. The data was collected from January to March 2016 among Polish professional project members.

The sample size was 305 respondents, 225 cases were accepted for further analysis, after rejecting faulty and incomplete questionnaires. The analysis was conducted using the structural equation modelling method. For the theoretical model presented in Figure 1, a measurement and later a structural Confirmatory Factor Analysis (CFA) models have been developed. The model was then estimated and assessed. Estimation was conducted according to a maximum likelihood method (ML). The evaluation of the model quality was conducted based on tests such as: Root Mean Square Error of Approximation (RMSEA), CMIN/DF, Comparative Fit Index (CFI), and HOELTER with the use of SPSS AMOS 23 software. Table 1 presents test results of the model's goodness of fit [67].

Based on the readings, CFA model presented in Figure 2 may be considered as well fit in relation to the data. Model reliability level 1.95 can be viewed as high, with the reference $\leq 5$ [62]. Model fit to the data based on approximation average error RMSEA at 0.065 also meets the reference values [63] below 0.08. Measurements of goodness of fit came close to 1 , what confirms the mentioned above quality [64]. Hoelter's coefficient exceeded 146, which also corroborates the above statements [65]. A positive evaluation of the model allows to proceeding to the presentation of test results.

Table 1. Test results of the model's goodness of fit

\begin{tabular}{|c|c|c|c|c|c|c|c|}
\hline CMIN/DF & RMSEA & NFI & RFI & IFI & TLI & CFI & HOELTER 0.05 \\
\hline 1.95 & 0.065 & 0.92 & 0.90 & 0.96 & 0.95 & 0.96 & 146 \\
\hline
\end{tabular}

Source: author's own study developed with Amos 23

Note: $\mathrm{Cmin} / \mathrm{df}=1.95, \mathrm{CFI}=0.96, \mathrm{TLI}=0.95 \mathrm{p}<0.001$, RMSEA $=0.065, \mathrm{~ns}$ - not significant result, $\mathrm{n}=225$ cases 


\subsection{Results}

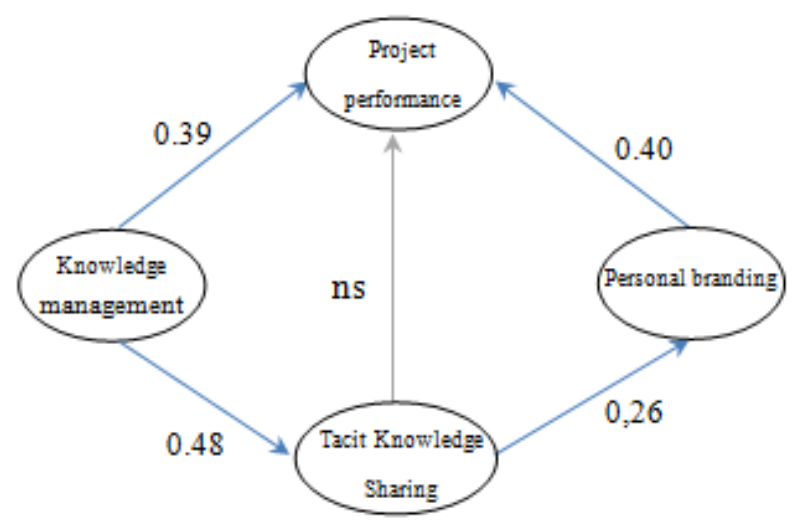

Figure 2. Results

Source: author's own study developed with Amos 23

Note: $\mathrm{CMin} / \mathrm{df}=1.95, \mathrm{CFI}=0.96, \mathrm{TLI}=0.95 \mathrm{p}<0,001, \mathrm{RMSEA}=0.065$ CI (0.05-0.08), ns - not significant result, $\mathrm{n}=225$ cases [67]

The results indicate that personal brands of knowledge workers are built with the use of tacit knowledge sharing, which affects final project performance. As a result, there is not a direct influence of tacit knowledge sharing on project performance but the influence is indirect, it is strongly mediated by personal branding activities. These results highlight the specific nature of tacit knowledge which is strongly related and exclusively stored in the human mind thus tacit knowledge sharing (distribution) is strongly related to the expected personal benefit such as positive personal brand reputation as a knowledgeable person. Figure 2 presents achieved results [67].

Table 2 presents a summary of the hypothesis tests referring to the theoretical model presented in Figure 1 [67].

Keeping in mind the objective of this study, which is to highlight that personal branding of knowledge workers can be a natural motivator to share their tacit knowledge, the estimations of the total effects of the model were analysed. Table 3 presents statistics crucial for personal branding mediation function analysis [67].

The analysis of the direct and indirect estimations, and the total effects presented in Table 3 show that tacit knowledge has a not significant direct impact on project performance, which is surprising in light of the theoretical assumptions made and described in the Introduction and Conceptual Framework sections. Only in the case of Knowledge Management and Personal Branding constructs the presented model notes a statistically significant influence on Project Performance. It means that Personal Branding strongly mediates the relation between Project Performance and Tacit Knowledge Sharing.

Table 2. Summary of the hypothesis tests

\begin{tabular}{|c|c|c|c|c|c|}
\hline \multicolumn{2}{|c|}{ Hypothesis } & B & t-value & p-value & supported \\
\hline H1 & Knowledge Management has positive influence on Project Performance & 0.38 & 4.72 & $<0.001$ & YES \\
\hline H2 & Knowledge Management has a positive influence on Tacit Knowledge Sharing & 0.48 & 5.89 & $<0.001$ & YES \\
\hline H3 & Tacit Knowledge sharing has a direct positive influence on Project Performance & -0.03 & -0.41 & 0.68 & NO \\
\hline H4 & $\begin{array}{c}\text { Tacit Knowledge sharing has a positive influence on Personal Branding of the team } \\
\text { member, who shares his own tacit knowledge }\end{array}$ & 0.26 & 3.38 & $<0.001$ & YES \\
\hline H5 & $\begin{array}{c}\text { Personal Branding of team members has a positive influence on Project } \\
\text { Performance }\end{array}$ & 0.40 & 5.81 & $<0.001$ & YES \\
\hline
\end{tabular}

Source: author's own study developed with Amos 23

Note: $\mathrm{CMin} / \mathrm{df}=1.95, \mathrm{CFI}=0.96, \mathrm{TLI}=0.95 \mathrm{p}<0.001, \mathrm{RMSEA}=0.065 \mathrm{CI}(0.05-0.08)$, ns - not significant result, $\mathrm{n}=225$ cases [67]

Table 3. Mediation analysis

\begin{tabular}{|c|c|c|c|c|}
\hline Mediation analysis & $\begin{array}{c}\text { Standardised total effect } \\
\text { (without mediator) }\end{array}$ & $\begin{array}{c}\text { Standardised Direct effect } \\
\text { (with mediator) }\end{array}$ & $\begin{array}{c}\text { Standardised Indirect effect } \\
\text { (with mediator) }\end{array}$ & $\begin{array}{c}\text { Mediation type } \\
\text { observed }\end{array}$ \\
\hline $\begin{array}{c}\text { Tacit Knowledge Sharing } \\
\text {->Personal Branding } \\
->\text { Project Performance }\end{array}$ & $0.07(*)$ & $-0.03(*)$ & $0.10(* * *)$ & full mediation \\
\hline
\end{tabular}

Source: author's own study developed with Amos 23

Note: $\mathrm{CMin} / \mathrm{df}=1.95, \mathrm{CFI}=0.96, \mathrm{TLI}=0.95 \mathrm{p}<0.001 \mathrm{RMSEA}=0.065$ CI $(0.05-0.08),{ }^{*} \mathrm{p}<0,1 * * \mathrm{p}<0.01 * * * \mathrm{p}<0.001 \mathrm{n}=225$ cases [67] 


\section{Conclusions}

The presented model explains the mechanism of how Tacit Knowledge Sharing mediated by Personal Branding influences Project Performance. The aim of this study, which was successfully achieved, was to prove that tacit knowledge sharing is a tool that builds a personal brand of knowledge workers in a project environment. However, a surprising result of the presented study is the lack of direct influence of tacit knowledge on project performance - a fact which denies our theoretical assumptions. Perhaps the specifics of project management, which before going to work requires precisely defined goals, tools, risk register and methods, does not allow much space for tacit knowledge sharing and that is why the assumptions are wrong. What's more, it's claimed that tacit knowledge is generally difficult to measure [70]. On the other hand, perhaps it is the tacit knowledge itself that justifies such subtle impact on project performance as presented in our study. It is worth noting that the presented model (Figure 2) explains the construct of Tacit Knowledge Sharing in 23\%, whereas Project Performance in 33\%, which has been presented in Appendix 2, Squared Multiple Correlations. The situation gives basis to thinking that there are other factors, not included in the presented model, which affect Tacit Knowledge Sharing, which have a significant intermediary significance for the Tacit Knowledge Sharing and Project Performance relationship, and which could be further analysed in order to explain the relation [69]. In view of the above, the presented model should be extended. Special attention should be paid to the intermediary role of personal branding in the relationship of tacit knowledge sharing and project performance. The conclusion related to the importance of soft skills corroborates the Ryan and O'Connor's [58] study results which pointed out that social interactions are more important than transactive memory systems (TMS) in the process of knowledge sharing. Presented results highlight the specific nature of tacit knowledge which is strongly related to social capital. The human minds which exclusively produce and store the tacit knowledge independently decide about distribution or keeping the new knowledge for itself. The tacit knowledge sharing act is strongly related to expected personal benefits such as positive personal brand reputation as a knowledgeable person. As a tacit knowledge sharing motivator, personal brand development can be a tool for designing incentive schemes creation. Tacit knowledge as a source of innovation, positive enhances the growth of innovation success. The innovation understood not only as an outstanding and brilliant new idea of a product, a service or general growing business but also as a new more effective way for everyday routines making or unexpected events solving what altogether positively impact on the final performance in the short and in the long run.

A significant limitation to the presented studies is a relatively low number of the sample group. Any structural equation modelling methodology allows the sample number to be 200 cases [65]. However, it is the presented HOELTER's index 0.05 at 146 level which proves that a bigger sample group would deliver better results. This study extends the understanding of personal branding role of tacit knowledge sharing in project teams. If we however assume that tacit knowledge, through its other indirect variables not included in the presented model and in accordance with the presented theoretical argumentation, affects project performance, then personal branding, as one of the significant mediating variables between tacit knowledge and project performance, can be taken into consideration when designing incentive schemes. For example, after a finished project, except for assessing its hard results project performance evaluation, the participants in the project would assess one another's attitude including tacit knowledge sharing (each person assesses all his co-workers). Conducting such assessment on regular basis by project organisations would affect quality growth of human resources in a significant way.

In the light of the presented results and in the reference to the existing literature [69] tacit knowledge sharing can be perceived as a very sensitive and specific variable interesting for further research. As it's claimed knowledge can be mediated not only on formal but also on informal ways [70]. For the deeper understanding of tacit knowledge sharing influence (direct or mediated) on the project performance important is the further examination in case of not only the new dimensions and sample structure factors such as age, gender and position but also in the case of the industry and the company culture which influence on the general organisation's and their members ability to learn and unlearn $[69,70]$. Tacit knowledge is very often accumulated through learning process inside organisations. One of the reasons why network relationships are established is that these relationships give access to new contextual knowledge. Network formation may be stimulated by government programs supporting projects of cooperation as is claimed by Lundvall [70]. The deeper examination of tacit knowledge dimensions can lead to the interesting practical implications.

The most valuable practical implication based on the results presented in this article is that knowledge workers today exists as independent tacit knowledge producers distributors and the awareness and the meaning of their personal brands is growing in fact. Thus, organisations should respect it if want to grow. 
Tacit Knowledge Sharing and Project Performance.

Does the Knowledge Workers' Personal Branding Matter?

\section{Appendix 1}

\section{Constructs and Scales}

\begin{tabular}{|c|c|c|c|}
\hline Construct & Scale & Adapted from & Scale validation \\
\hline $\begin{array}{l}\text { Knowledge } \\
\text { Management } \\
\quad(\mathrm{KM})\end{array}$ & $\begin{array}{l}\text { Members of the project team had access to a knowledge management system } \\
\text { Members of the project team trusted each other to act professionally and } \\
\text { competently } \\
\text { Members of the project team viewed themselves as having knowledge and } \\
\text { learning orientation within the project } \\
\text { Members of the project communicate easily to act professionally and } \\
\text { competently }\end{array}$ & $\begin{array}{l}\text { Gemino, Reich, Sauer } \\
\text { (2015) }\end{array}$ & $\begin{array}{c}\text { Cornbach } \alpha=0.76 \\
\quad \mathrm{AVE}=0.56 \\
\mathrm{CR}=0.83\end{array}$ \\
\hline $\begin{array}{l}\text { Tacit } \\
\text { Knowledge } \\
\text { Sharing }(\mathrm{TpS})\end{array}$ & $\begin{array}{l}\text { I shared my experience and know-how with team members of the project } \\
\text { I shared my experience and know-how with my functional co-workers in my } \\
\text { organisation } \\
\text { I extracted new knowledge from the project team members based on their } \\
\text { experience and know-how that helped me follow up the project } \\
\text { I extracted new knowledge and know-how from experts and functional } \\
\text { co-workers in my organisation that helped me follow up the project } \\
\text { Overall, members of the project team shared their experience and know-how }\end{array}$ & $\begin{array}{l}\text { Gemino, Reich, Sauer } \\
\text { (2015); Park, J. G., Lee, } \\
\text { J. (2014); } \\
\text { Hau et al (2013) }\end{array}$ & $\begin{array}{c}\text { Cornbach } \alpha=0.84 \\
\text { AVE }=0.57 \\
\text { CR }=0.87\end{array}$ \\
\hline $\begin{array}{c}\text { Personal } \\
\text { Branding (PB) }\end{array}$ & $\begin{array}{l}\text { Sharing tacit knowledge affected my image in a positive way } \\
\text { Sharing tacit knowledge evoked good associations about my person } \\
\text { Sharing tacit knowledge had a positive influence of other people in the } \\
\text { project towards me } \\
\text { Sharing tacit knowledge had a positive influence on my reputation }\end{array}$ & $\begin{array}{l}\text { Kheder (2014) - } \\
\text { definition of personal } \\
\text { brand, Ajzen (2002)- } \\
\text { theory of planned } \\
\text { behaviour, Babbie (2013) }\end{array}$ & $\begin{array}{c}\text { Cornbach } \alpha=0.85 \\
\quad \mathrm{AVE}=0.64 \\
\mathrm{CR}=0.84\end{array}$ \\
\hline $\begin{array}{l}\text { Project } \\
\text { Performance } \\
\text { (PP) }\end{array}$ & $\begin{array}{l}\text { Sponsor of the project was satisfied with the project results } \\
\text { Sponsor of the project was satisfied with the project benefits } \\
\text { Sponsor of the project assessed the project positively }\end{array}$ & $\begin{array}{l}\text { Gemino, Reich, Sauer } \\
\text { (2015), Babbie (2013) }\end{array}$ & $\begin{array}{c}\text { Cornbach } \alpha=0.93 \\
\text { AVE }=0.82 \\
\mathrm{CR}=0.93\end{array}$ \\
\hline
\end{tabular}

Source: author's own study with the use of SPSS AMOS 23 [67]

Factor correlation matrix with square root of the AVE on the diagonal

\begin{tabular}{|c|c|c|c|c|c|c|c|}
\hline & AVE & CR & Cornbach $\alpha$ & KM & Tps & PB & PP \\
\hline KM & 0,56 & 0,83 & 0,76 & $\mathbf{0 , 7 5}$ & & & \\
\hline Tps & 0,57 & 0,87 & 0,84 & 0,48 & $\mathbf{0 , 7 5}$ & & \\
\hline PB & 0,64 & 0,84 & 0,84 & 0,12 & 0,26 & $\mathbf{0 , 8 0}$ & \\
\hline PP & 0,82 & 0,93 & 0,93 & 0,42 & 0,26 & 0,44 & $\mathbf{0 , 9 1}$ \\
\hline
\end{tabular}

Source: author's own study with the use of SPSS AMOS 23 [67]

\section{Appendix 2}

Squared Multiple Correlations: (Group number 1 - Default model)

\begin{tabular}{|c|c|}
\hline & Estimate \\
\hline KM & .000 \\
\hline TpS & .232 \\
\hline PB & .066 \\
\hline PP & .334 \\
\hline
\end{tabular}

Source: authors own study with the use of SPSS AMOS 23 [67]

Regression Weights: (Group number 1 - Default model)

\begin{tabular}{|c|c|c|c|c|c|c|c|}
\hline & & & Estimate & S.E. & C.R. & P & Label \\
\hline TpS & $<--$ & $\mathrm{KM}$ & 1.051 & .178 & 5.895 & $* * *$ & $* * *$ \\
\hline PB & $<--$ & $\mathrm{TpS}$ & .183 & .054 & 3.378 & $* * *$ & par_11 \\
\hline PP & $<--$ & $\mathrm{KM}$ & .460 & .097 & 4.723 & $* * *$ & par_4 \\
\hline PP & $<--$ & PB & .307 & .053 & 5.810 & .680 & par_8 \\
\hline PP & $<--$ & TpS & -.017 & .042 & -.413 & par_13 \\
\hline
\end{tabular}

Source: authors own study with the use of SPSS AMOS 23 [67] 
Standardized Regression Weights: (Group number 1 - Default model)

\begin{tabular}{|c|c|c|c|}
\hline & & & Estimate \\
\hline $\mathrm{TpS}$ & $<---$ & $\mathrm{KM}$ & .482 \\
\hline PB & $<---$ & $\mathrm{TpS}$ & .256 \\
\hline PP & $<---$ & $\mathrm{KM}$ & .388 \\
\hline PP & $<---$ & $\mathrm{PB}$ & .403 \\
\hline PP & $<---$ & $\mathrm{TpS}$ & -.032 \\
\hline ZW5 & $<---$ & KM & .787 \\
\hline ZW6 & $<---$ & $\mathrm{KM}$ & .693 \\
\hline ZW3 & $<---$ & $\mathrm{KM}$ & .675 \\
\hline PP2 & $<---$ & PP & .870 \\
\hline PP3 & $<---$ & PP & .933 \\
\hline PP1 & $<---$ & PP & .921 \\
\hline $\mathrm{Pb} 2$ & $<---$ & PB & .831 \\
\hline $\mathrm{Pb} 3$ & $<---$ & PB & .736 \\
\hline $\mathrm{Pb} 1$ & $<---$ & $\mathrm{PB}$ & .856 \\
\hline TpS4 & $<---$ & $\mathrm{TpS}$ & .745 \\
\hline TpS5 & $<---$ & $\mathrm{TpS}$ & .873 \\
\hline TpS6 & $<---$ & $\mathrm{TpS}$ & .831 \\
\hline ZW4 & $<---$ & $\mathrm{KM}$ & .826 \\
\hline TpS3 & $<---$ & $\mathrm{TpS}$ & .702 \\
\hline $\mathrm{TpS} 2$ & $<---$ & $\mathrm{TpS}$ & .611 \\
\hline
\end{tabular}

Source: authors own study with the use of SPSS AMOS 23 [67]

\section{REFERENCES}

[1] D. Tapscott. Creating Value in the Network Economy, Harward Business Review Book Series, 1999.

[2] K. Perechuda. Dyfuzja wiedzy w przedsiębiorstwie sieciowym. Wizualizacja i kompozycja, Wydawnictwo AE im. O Langego, Wrocław, 2007.

[3] G. Mazurek. Znaczenie wirtualizacji marketingu w sieciowym kreowaniu wartości, Poltext, Warszawa, 2012.

[4] A. Toffler. The third wave, Bantam books, New York, 1981.

[5] W. Powell. Neither market nor hierarchy. The sociology of organizations: classic, contemporary, and critical readings, Vol.315, 104-117, 2003.

[6] M. Sawhney, J. Zabin. Managing and Measuring Relational Equity in the Network Economy", Journal of the Academy of Marketing Science, Vol 4, No. 30, 313-332, 2012.

[7] S. D. Hunt, S. Madhavaram. The service dominant logic of marketing: Theoretical foundations, pedagogy, and resourceadvantage theory, in: R.F. Lusch, S.L. Vargo. The service-dominant logic of marketing: Dialog, debate and directions, Routledge, 2014.
[8] Eurostat. Online available from: http://ec.europa.eu/eurostat/statistics-explained/index.php/Em ployment_statistics\#Part-time_and_fixed-term_contracts

[9] B. Czarniawska. Trochę inna teoria organizacji. Organizowanie jako konstrukcja sieci działań, Poltext, Warszawa, 2010.

[10] S. E. Portny. Project management for dummies, John Wiley \& Sons, Indiana, 2010.

[11] C. McInerney. Knowledge management and the dynamic nature of knowledge, Journal of the American Society for Information Science and Technology, Vol.53, No.12, 1009-1018, 2002.

[12] L. Mládková. Knowledge Workers and the Principle of 3S (Self-management, Self-organization, Self-control), Procedia-Social and Behavioral Sciences, Vol.181, 178-184, 2015.

[13] L. Mládková, J. Zouharová, J. Nový. Motivation and Knowledge Workers, Procedia-Social and Behavioral Sciences, Vol.207, 768-776, 2015.

[14] A. Gemino, B.H. Reich, C. Sauer. Plans versus people: Comparing knowledge management approaches in IT-enabled business projects, International Journal of Project Management, Vol.33, No. 2, 299-310, 2015.

[15] Y. S. Hau, B. Kim, H. Lee, Y. G. Kim. The effects of individual motivations and social capital on employees' tacit and explicit knowledge sharing intentions, International Journal of Information Management, Vol.33, No.2, 356-325, 2013.

[16] J. G. Hunt, J. Lee. Knowledge sharing in information systems development projects: Explicating the role of dependence and trust, International Journal of Project Management, Vol.32, No.1, 153-165, 2014.

[17] S. C. Yang, C. K. Farn. Social capital, behavioural control, and tacit knowledge sharing-A multi-informant design, International Journal of Information Management, Vol.29, No.3, 210-218, 2009.

[18] J. Lindström, J. Delsing, T. Gustafsson,. Impact on Production Systems from Recent and Emerging Complex Business Models: Explicit and Tacit Knowledge Required, Procedia CIRP, Vol.38, 210-215, 2015.

[19] T. Young, N. Milton. Knowledge Management for Sales and Marketing, CP Chandos Publishing, Oxford, 2011.

[20] B. Wit, R. Meyer. Strategy Synthesis: Resolving Strategy Paradoxes to Create Competitive Advantage, Thomson Learning, 2005.

[21] M. Polanyi. The tacit dimension, Doubleday \& Company Inc., Garden City, New York, 1967.

[22] D. J. Hołodnik, K. Perechuda. Przedsiębiorstwo nowej generacji, Annales Universitatis Mariae Curie-Skłodowska, Sectio H-Oeconomia, Vol.50, No.2, 21, 2016.

[23] J. Lee. Heterogeneity, Brokerage, and Innovative Performance: Endogenous Formation of Collaborative Inventor Networks, Organization Science, Vol.21, No.4, 804-822, 2010.

[24] B. Solis. The end of business as usual: Rewire the way you work to succeed in the consumer revolution, John Wiley \& 
Sons, 2011.

[25] Deutsche Bank. Online available from: http://www.money.pl/d/popup.htm?http://static1.money.pl/i/h /105/b389993.png

[26] P. J Buckley, R. Strange. The governance of the global factory: location and control of world economic activity, Academy of Management Perspectives, Vol.29, No.2, 237-249, 2015.

[27] A. Crane. Modern slavery as a management practice: Exploring the conditions and capabilities for human exploitation, Academy of Management Review, Vol.38, No.1, 49-69, 2013.

[28] R. L. Sims, T. L. Keon. Ethical work climate as a factor in the development of person-organization fit, Journal of Business Ethics, Vol.16, No.1, 95-105, 1997.

[29] C. Viswesvaran, D. S. Ones. Examining the construct of organizational justice: A meta-analytic evaluation of relations with work attitudes and behaviors, Journal of Business Ethics, Vol.38, 198-203, 2002.

[30] C. M. Riordan, R. D. Gatewood, J. B. Bill. Corporate image: Employee reactions and implications for managing corporate social performance, Journal of Business Ethics, Vol.16, No.1, 401-412, 1997.

[31] E. M. Lee, S. Y. Park, H. J. Lee. Employee perception of CSR activities: Its antecedents and consequences, Journal of business research, Vol.66, No.10, 1716-1724, 2013.

[32] A. Singhapakdi, D. J. Lee, M. J. Sirgy, K. Senasu, K. The impact of incongruity between an organization's CSR orientation and its employees' CSR orientation on employees' quality of work life, Journal of Business Research, Vol.68, No.1, 60-66, 2015.

[33] A. Dabirian, J. Kietzmann, H. Diba. A great place to work!? Understanding crowdsourced employer branding, Business Horizons, Vol. 60, No.2, 197-205, 2017.

[34] F. Carbone, J. Contreras, J. Z. Hernández, J. M. Gomez-Perez. Open Innovation in an Enterprise 3.0 framework: Three case studies, Expert Systems with Applications, Vol.39, No.10, 8929-8939, 2012.

[35] A. Wildowicz-Giegiel. The Evolution of Organizational Culture in Polish Enterprises, Proceedings of the 2014 International Congress on Economy, Finance, and Business , Conference Organizers International Academy Institute National Taipei University International Business Academics Consortium (iBAC) Nagoya, Vol.2,144-156, 2014.

[36] M. Cronk. Social capital, knowledge sharing and intellectual capital in the web 2.0 enabled world, in: Gurteen, D. (Ed.) Leading Issues in Social Knowledge Management, Academic Conferences Limited, 2012.

[37] D. Gurteen. Leading issues in social knowledge management. Academic Conferences Limited, 2012.

[38] P. Wiśniewski. Intellectual Capital (IC) in Social Media Companies: Its Positive and Negative Outcomes, Proceedings of the 5th European Conference on Intellectual Capital: ECIC 2013, 455, Academic Conferences Limited, 2013.

[39] T. Peters. The brand called you, Fast Company, Vol.10, No.10, 83-90, 1997.
[40] S. Dutta. What's your personal social media strategy, Harvard Business Review, Vol.88, No.11, 127-130, 2010.

[41] I. Karaduman. The effect of social media on personal branding efforts of top level executives, Procedia-Social and Behavioral Sciences, Vol. 99, 465-473, 2013.

[42] I. D. Shepherd. From cattle and coke to Charlie: Meeting the challenge of self- marketing and personal branding, Journal of Marketing Management, Vol.21, No. 5-6, 589-606, 2005.

[43] L. I. Labrecque, E. Markos, G. R. Milne. Online personal branding: processes, challenges, and implications, Journal of Interactive Marketing, Vol.25, No.1, 37-50, 2011.

[44] C. Grönroos, P. Voima. Critical service logic: making sense of value creation and co-creation, Journal of the Academy of Marketing Science, Vol.41, No.2, 133-150, 2013.

[45] L. Leuthesser, C. Kohli, R. Suri. 2+ 2=5? A framework for using co-branding to leverage a brand, The Journal of Brand Management, Vol.11, No.1, 35-47, 2003.

[46] I. Ajzen. The theory of planned behaviour, Organizational behavior and human decision processes, Vol.50, No.2, 179-211, 1991.

[47] M. Khedher. Personal branding phenomenon, International Journal of Information, Business and Management, Vol.6, No.2, 29-40, 2014.

[48] B. E. Ashforth, F. Mael. Social identity theory and the organization", Academy of management Review, Vol.14, No.1, 20-39, 1989

[49] C. K. Kim, D. Han, S. B. Park. The effect of brand personality and brand identification on brand loyalty: Applying the theory of social identification, Japanese Psychological Research, Vol.43, No.4, 195-206, 2001.

[50] E. Wallace, I. Buil, L. de Chernatony. Consumer engagement with self-expressive brands: brand love and WOM outcomes, Journal of Product \& Brand Management, Vol.23, No.1, 33-42, 2014.

[51] W. O. Bearden M. J. Etzel. Reference group influence on product and brand purchase decisions, Journal of Consumer Research, 183-194, 1982.

[52] J. E. Escalas, J. R. Bettman. Self-construal, reference groups, and brand meaning, Journal of Consumer Research, Vol.32, No.3, 378-389, 2005.

[53] E. H. Erikson. The problem of ego identity, Journal of the American Psychoanalytic Association, Vol.4, No.1, 56-121, 1956.

[54] K. Kang. Branding Pays, Branding Pays Media, 2013.

[55] A. K. Munns, Potential influence of trust on the successful completion of a project, International Journal of Project Management, Vol.13, No.1, 19-24, 1995.

[56] M.P. Buvik, M. Rolfsen. Prior ties and trust development in project teams-A case study from the construction industry, International Journal of Project Management, Vol.33, No. 7, 1484-1494, 2015.

[57] W. Rutten, J. Blaas-Franken, H. Martin. The impact of (low) trust on knowledge sharing. Journal of Knowledge Management, Vol.20, No.2, 199-214, 2016. 
[58] S. Ryan, R. V. O'Connor. Acquiring and sharing tacit knowledge in software development teams: An empirical study, Information and Software Technology, Vol.55, No.9, 1614-1624, 2013.

[59] I. H. S. Chow. The role of social network and collaborative culture in knowledge sharing and performance relations, SAM Advanced Management Journal, Vol.77, No.2, 24-33, 2012.

[60] B. H Reich, A. Gemino, C. Sauer. How knowledge management impacts performance in projects: An empirical study, International Journal of Project Management, Vol.32, No.4, 590-602, 2014.

[61] A. Calvo-Mora, A. Navarro-García, R. Periañez-Cristobal. Project to improve knowledge management and key business results through the EFQM excellence model, International Journal of Project Management, Vol.33, No.8, 1638-1651, 2015.

[62] D. E. Wheaton. Assessing reliability and stability in panel models, Sociological methodology, San Francisco: Jossey-Bass, 1977.

[63] J. H. Steiger, J. C. Lind, Statistically based tests for the number of common factors, Annual meeting of the Psychometric Society, Iowa City, IA, Vol. 758, 1980.

[64] K. A. Bollen. Sample size and Bentler and Bonett's nonnormed fit index, Psychometrika, Vol.51, No.3, 375-377, 1986.

[65] J. W. Hoelter. The analysis of covariance structures goodness-of-fit indices", Sociological Methods \& Research, Vol.11, No.3, 325-344, 1983.

[66] S. Ryan, R. V. O'Connor. Acquiring and sharing tacit knowledge in software development teams: An empirical study, Information and Software Technology, Vol.55, No.9, 1614-1624, 2013.

[67] W. Kucharska, J. Dąbrowski. Tacit Knowledge Sharing and Personal Branding: How to Derive Innovation from Project Teams? Proceedings of the 11th European Conference on Innovation and Entrepreneurship: ECIE 2016, 435-443. 2016.

[68] W. Kucharska. Consumer social network brand identification and personal branding. How do social network users choose among brand sites? Cogent Business \& Management, Vol. 4, No.1, 1315879, 2017.

[69] W. Kucharska, R. Kowalczyk, M. Kucharski. Trust, Tacit Knowledge Sharing, Project Performance and their Managerial Implications. Proceedings of the 18th European Conference on Knowledge Management: ECKM 2017, Vol 1, 532-539. 2017.

[70] B. A. Lundvall. The Learning Economy and the Economics of Hope, Anthem Press, 2017. 